\title{
Irrigation Suitability Assessment of Effluents From West Kano Rice Irrigation Scheme, Kisumu, Kenya Afullo Otieno Augustine*
}

\begin{abstract}
This paper assesses the suitability of West Kano Rice Irrigation Scheme effluents for recycling. Water and wastewater quality variables of ten samples from two sites were determined. The variables were Temperature, Electrolytic conductivity, Total suspended solids, pH, Calcium, Nitrates, Potassium, Sodium and Total Dissolved Solids (TDS). The results were used to compute the Sodium adsorption ratio (SAR), and further compared with FAO irrigation water standards. The wastewater recorded statistically significant gain in Calcium, Nitrates, and TDS, depicting a heavy loss of these vital soil constituents to Lake Victoria. Nitrate levels indicated a deficit in lake water, and an excess in effluents. The excess nitrates in effluents pollute the lake, but could help as crop nutrients when recycled, while low nitrate levels in the lake water would require an addition of fertilizers to the irrigated soils. Annually, a total of 12.26 million $\mathrm{m}^{3}$ of water and 8.94 million $\mathrm{m}^{3}$ of effluents is pumped into and out of the scheme respectively. The effluent and Lake water has SAR of $35 \%$ and $18 \%$ respectively, rendering both of poor irrigation quality, though the effluents have a compensatory advantage due to its higher levels of Calcium $(0.91 \mathrm{me} / \mathrm{l})$, compared with the Lake water's $0.48 \mathrm{me} / \mathrm{l}$. The wastewater, with an irrigation suitability rating of $45 \%$, was found more suitable for irrigation than the Lake water's $40 \%$. It was concluded that the irrigation wastewater was more suitable for use in the scheme than the Lake Victoria waters. It was recommended that the recycling of the irrigation wastewater should be adopted.
\end{abstract}

Key Words: Irrigation; Recycling; Pollution; Waste; Water Quality; Wastewater.

\section{Introduction}

$$
S_{\text {Kenya Ince the inception of the West }}^{\text {Ingation }} \text { Schemes- }
$$

Bunyala, West Kano Rice Irrigation Scheme(WKRIS), and Ahero about four decades ago, sustainability of irrigation has been questioned (Afullo, 1995; Kinyali, 1973; and Wandhahwa, 1988). The electrolytic conductivity (EC) of the Lake Victoria waters is less than $200 \mu \mathrm{Scm}-1$ which is classified as low salinity water (Ayers and Westcott, 1985), capable of impoverishing irrigated soils by removing their divalent cations through leaching, and increasing their Exchangeable Sodium Percentage (ESP), thereby destabilizing their structure and rendering them deffloculated. Sulphate of Ammonia (SOA) acidifies soils (Russel, 1973), with a possibility of causing heavy soil Calcium ion losses in the form of Calcium nitrate and Calcium sulphate. These are likely to be lost in the irrigation effluents. In WKRIS Calcium and Nitrate enriched effluent is disposed of into Lake Victoria, where it has already caused wanton eutrophication, as exemplified by the water hyacinth (Eichhornia crassipes) invasion, while the irrigated soils which lose the $\mathrm{Ca}^{2+}$ are bound to be deflocculated (Afullo, 1995). Thus whereas, the current irrigation has the potential to cause eutrophication of aquatic systems and deflocculating the irrigated soils, the effluent, from theoretical perspective, is capable of solving these challenges through recycling. It is the prospects of containing these twin environmental catastrophes that is being investigated by this study, through an assessment of suitability of the WKRIS effluent for recycling. This research was designed to help answer the following questions: (i) What is the physico-chemical quality of Lake Victoria waters and that of effluents?; (ii) Is there a variation in physicochemical quality of Lake Victoria waters and the WKRIS irrigation effluents, and if so, how significant is the difference? ; (iii) Is the WKRIS effluent suitable for re-use in rice irrigation? ; and (iv) Which water source is better for irrigation between Lake Victoria waters and the WKRIS effluents?. The goal of the study was to determine the recycling potential for the current WKRIS effluents, with the following specific objectives: (a) To compare the physico-chemical quality of WKRIS current irrigation waters and its irrigation effluents; and (b) To assess the suitability of the WKRIS effluents for reuse in irrigation.

\section{Literature Review}

Kenya, like most tropical countries, has a rapidly increasing population and a consequent need for greater food production. The country does not have a large arable land which could provide a sufficient resource for agriculture. Increasing food production requires modern mechanised farming methods coupled with use of fertilisers, pesticides and irrigation. In Africa, most green revolution projects were implemented without 
environmental impact assessments (EIA), which in Kenya, became mandatory from 2003 following the implementation of the Environmental Management and Coordinating Act (EMCA) (1999). However, even then, only very few government institutions comply with the act. This poses a great challenge to sustainable development (Lebel and Kane, 1987). Many agricultural projects such as irrigation projects have become unsustainable because they destroy the resource base (Mason, 2002, Afullo, 1995). There is thus a need to continuously monitor the effects of these developments on the environment. Inappropriate utilisation of natural water resources is destroying the resource base, rendering access to good quality water a big challenge (GoK, 2005; NIB, 1999; ILACO, 1977). Valuable soils are lost through erosion, leaching and salinization. But Kenya has limited feasible choices to make (GoK, 1998, 2003). She must expand cropping area through irrigation, use appropriate agriculture and conduct research to enable it utilise the $80 \%$ of its land resource which is classified as low potential. In this effort to ensure sustainability in agriculture, pollution is a major threat (GoK, 2003). Kenya must continue to actively search for alternative water sources for agriculture to avoid polluting the limited fresh water resources. This is significant since Kenya is classified as a water scarce country (Smet and Wijk, 2002).

In 2009, Kim et al. conducted a study on estimation of irrigation return flow from paddy fields considering the soil moisture. The objective of this study was to estimate irrigation return flow in irrigated paddy fields considering the soil moisture. The estimated average annual irrigation return flow during the period from 1998 to 2001 was $306.2 \mathrm{~mm}$, which was approximately $25.7 \%$ of the annual irrigation amounts. Of this annual irrigation return flow, $14.1 \%$ was attributable to quick and $11.6 \%$ to delayed return flow. These results indicate that considerable amounts of irrigation water in the paddy fields were returned to streams and canals by surface runoff and groundwater discharge. The modelling assessment method proposed in this study can be used to manage agriculture water and estimate irrigation return flow under different hydrological and water management conditions (Kim et al, 2009).
Mohan and Vijayalakshmi (2009) conducted a study on Prediction of irrigation return flows through a hierarchical modeling approach. The researchers found out a pressing need to improve the water efficiency of irrigation systems. It identified one-way of improving the efficiency of the irrigation system as reusing the return flow from the irrigation system. They felt that the task required quantification of return flow, which still remained as a grey area in irrigation water management. Afullo (1995) did a Lake Victoria pollution study in WKRIS, and found out that the current water source was too corrosive to the soils, and recommended an alternative irrigation water source. D'Costa's (1973) soil survey, which characterised and interpreted the soils of Kano Plains for irrigated agriculture, gave important insights into further development of the Kano Plains, and identified the current site of WKRIS for the next phase of development. It dwelt on the soil physico-chemical characteristics for the different locations in the Kano Plains, and identified the then Kawino and Nyamware Sub locations for the WKRIS establishment, based on their soil characteristics. Mukumbu (1987) studied the optimal enterprises mix and the resources allocation for WKRIS and identified problems such as: high operational and maintenance expenses; high pumping and drainage costs; and inefficient water management.

Afullo (1995) assessed the sustainability of irrigation in the WKRIS by sampling and laboratory analysis of water from 7 different points. The researcher found out that the irrigation in the WKRIS is not sustainable due to excessive pollution of the water source, Lake Victoria by silt, clay, Nitrates and sulphides. This partly contributed to the current ecological crisis of water hyacinth (Eichhornia crassipes) in the lake, which is threatening the survival of the irrigation water source. The researcher recommended a study of water use efficiency in the WKRIS, as well as the suitability of the effluent for reuse in irrigation. It is in the strength of this finding that this research is being conducted. There has been no specific study on effluent reuse assessment in any of the West Kenya irrigation schemes. A socioeconomic and environmental impact assessment research done in Swaziland and Nigeria by Urama and Mwendera (2005), 
found out that irrigation reduced the productive capacity of river flood plains, while creating the illusion of increased crop productivity in the project areas. Its environmental impact were reflected in degraded soils, increased health risks to farm households, water resource extraction for irrigation was high, unregulated and incorrectly priced it recommended proper water resource pricing and management, and adequate monitoring of the schemes in both countries. It is also observed the importance of tracking these subtle changes in soils and water quality for effective control of the social and environmental problems that had been observed so far (Kim et al, 2009).

\section{Study Area}

The WKRIS is bounded to the west by Lake Victoria, to the north and south by Nyando and Nyabondo escarpments respectively, and to the east by the footsteps of
Tinderet highlands. It occupies the major part of Kano plains proper which is located between longitudes 34"48' and 35"02' and between latitudes 00"04' and 00"20' south (D'Costa, 1973), and lies to the eastern side of the shores of Winam Gulf of Lake Victoria (figure 1). It occupies 841 hectares (ha) at an altitude of $1137 \mathrm{~m}$ above sea level, receives a mean annual precipitation of $1100 \mathrm{~mm}$, potential evapo-transpiration loss of $2200 \mathrm{~mm}$ per annum, mean diurnal temperature of $23^{\circ} \mathrm{C}$, and a relative humidity of $68-70 \%$. The WKRIS has mainly the 2:1 clays of the type vertisol soils belonging to group 1 of the USDA soil irrigation suitability classification (D'Costa, 1973). They are fine textured, dark, blocky soils low in organic matter which shrink and crack appreciably with the changes in moisture content and commonly lack distinct horizons.

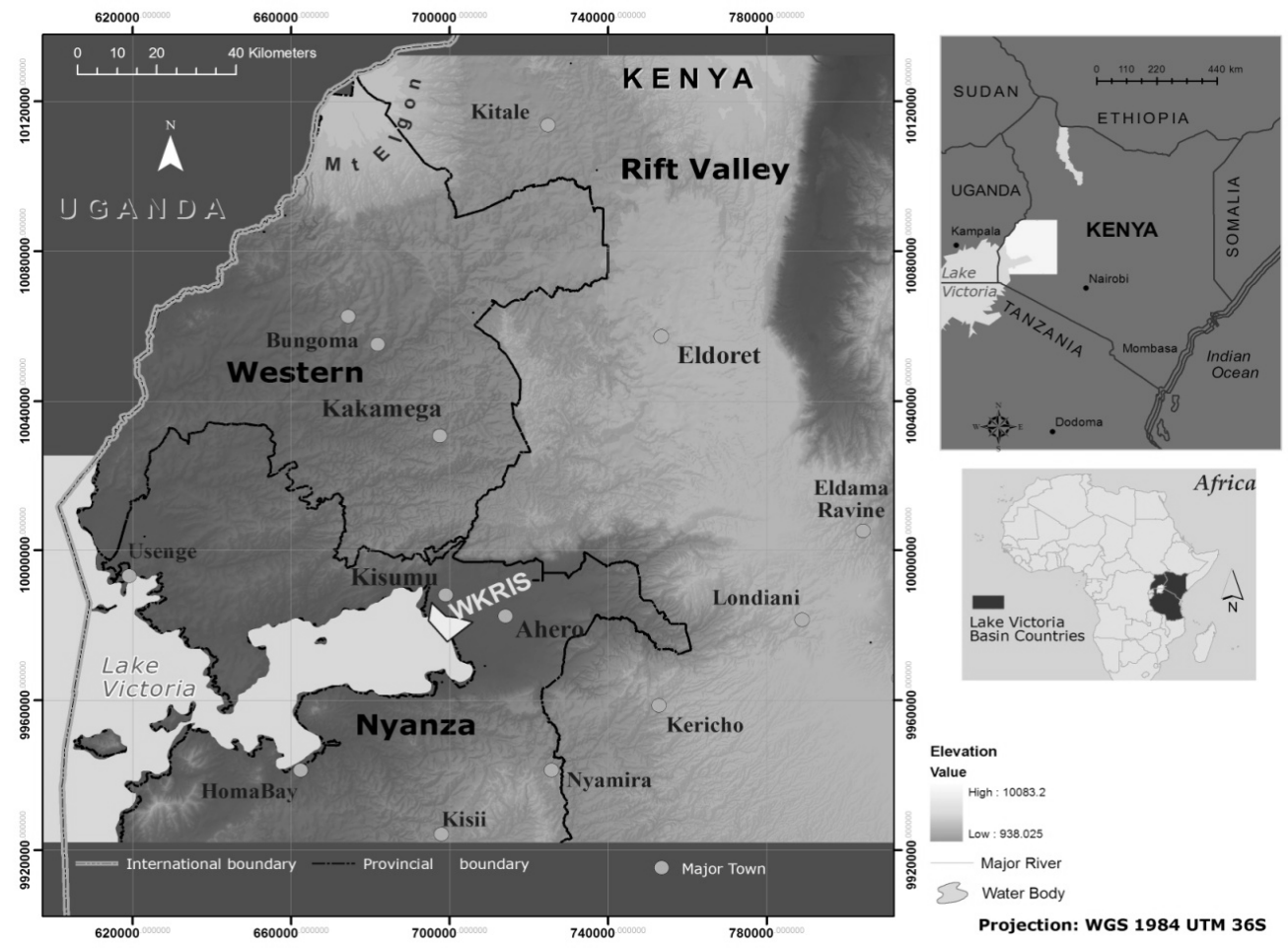

Figure 1: The study area (WKRIS) 


\section{Methodology}

The study was accomplished by sampling and chemical laboratory analysis in triplicate of Lake Victoria water at inlet and WKRIS effluent immediately it comes from the paddy fields (samples 1 and 2 respectively). The means were computed results were statistically compared using the student t-test and Analysis of variance (ANOVA) to determine if there was any statistically significant difference in the quality of these two water sources with respect to specific chemical and physical parameters. To be able to get further technical and other qualitative data to enable the researcher attach meaning to some of the quantitative data, Key Informant Interviews of the key personnel and stakeholders of WKRIS were conducted. Transect walk, field visit and interviews were also done to assess the operational challenges evident in the scheme, and also to get records of pumping rates and volumes. The laboratory analysis results were statistically analysed, and the means compared with irrigation water standards. The results were put in a table, used to compute other irrigation and water quality parameters such as the ESP, SAR, among others. These were used to make major conclusions and recommendations. Ten water samples were collected from each point, 1 and 2. Point 1 was a control point with water perceived to be clean, unpolluted by the operations of the WKRIS. Point 2 was the WKRIS irrigation effluent. The filtering and the bottle washings were done as per the APHA et al (2005) recommendations. Before every sampling, the container was washed thrice with the water from the sampling site. Then three samples of equal volume were each sampled from $10 \mathrm{~cm}, 20 \mathrm{~cm}$ and $30 \mathrm{~cm}$ depths and mixed to produce a composite sample. From this, a 500-ml representative sample was put into the containers for analysis. Sampling was done and samples stored in a cooling box and immediately taken to the laboratory. For the rest of the parameters, the water samples were deep-frozen until analysis. Field parameters such as temperature, $\mathrm{pH}$, and Electrolytic conductivity (EC) were determined and recorded immediately after sampling. In each sample, analysis was done in triplicate, with each parameter giving 30 sets of results whose means, standard errors and standard deviation were calculated as indicated in table 5 at $95 \%$ confidence limit.

The criteria for selecting the chemical analytical methods were recommendations by (a) Kovda et al (1973). (b) Hunt and Wilson, 1986 (c) (APHA et al, 2005). These references gave suitable analytical methods for each selected chemical and physical water quality parameter as: (1) $\mathrm{Na}$ and K-flame photometer (APHA et al, 2005, and Kovda et al (1973)) (2) $\mathrm{Ca}$ and $\mathrm{Mg}$-Flame photometer or titration with EDTA using Eriochrome Black T as indicator (Kovda et al (1973)(3) Carbonate and bicarbonate-Titration with sulphuric acid to (i) phenolphthalein end point for carbonate, and to (ii) methyl orange end point for bicarbonate (APHA et al, 2005); (4) NitratesColorimetrically using the sulfanilic acid Kovda et al (1973);(7) Dissolved solids(salinity)-(APHA et al, 2005), and Gregg (1989); (8) Suspended solids- APHA et al, 2005; (9) Electrolytic conductivity-Wheatstone bridge measurement (Gregg, 1989). The data acquired were expressed in milligrams per litre $(\mathrm{mg} / \mathrm{l})$, except for temperature, EC and $\mathrm{pH}$. They were analysed and mean values for each parameter per sampling point presented in tables 1-6 as shown below. They were analysed and interpreted using student t-test and one way Analysis of Variance (ANOVA) shown in tables 3 and 4 , and irrigation usesuitability standards for seventeen different parameters in table 6 . These were used to compare difference in concentration of parameters in samples 1 and 2, using rating and scoring.

\section{Results and Discussion}

The levels of different parameters determined in the samples 1 and 2 are shown in tables 1,2 and 3 and then compared in figure 2. The $\mathrm{Ca}^{2+}$ levels were $9.9900 \pm 0.0586 \mathrm{mg} / \mathrm{l}$ in lake water (point 1) and $17.9933 \pm 0.0661 \mathrm{mg} / \mathrm{l}$ for effluents (point 2); $\mathrm{Mg}^{2+}$ levels were $25.9833 \pm .0384 \mathrm{mg} / \mathrm{l}$ and $32.9900 \pm .0729 \mathrm{mg} / \mathrm{l}$ for point 1 and 2 respectively; $\mathrm{Na}^{+}$levels were $4.9967 \pm .0290$ $\mathrm{mg} / \mathrm{l}$ and $11.000 \pm .0875 \mathrm{mg} / \mathrm{l}$ in points 1 and 2 respectively; The $\mathrm{K}^{+}$levels were $3.9900+.0260$ $\mathrm{mg} / \mathrm{l}$ and $9.0033 \pm .0454 \mathrm{mg} / \mathrm{l}$ for points 1 and 2 respectively. Other were: $\mathrm{NO}_{3}{ }^{-}-4.9867 \pm 0.0291$ $\mathrm{mg} / \mathrm{l}$ in point 1 and $46.9897+.1468 \mathrm{mg} / \mathrm{l}$ in point 2; TDS of $102.000 \pm .2537 \mathrm{mg} / \mathrm{l}$ for point 1 and $207.0000+.5425 \mathrm{mg} / \mathrm{l}$ for point 2 ; TSS of $12.0033 \pm .0379 \mathrm{mg} / \mathrm{l}$ in point 1 and 
$38.0067 \pm .1602 \mathrm{mg} / \mathrm{l}$ for point 2 ; an EC level of $110.0000+.2796 \mathrm{\mu Scm}^{-1}$ for point 1 and $187.0000 \pm .3140 \mu \mathrm{Scm}^{-1}$ for point 2 . In all the parameters measured, point 2, representing effluents, consistently show an enrichment as shown in table 5 . These results indicate a general enrichment of the waters between the time they reach the scheme, and the time they are being pumped out. Table 3 indicates that according to the student t-test, the level of $\mathrm{NO}_{3}{ }^{-}$is statistically significant between point 1 and point 2, while there is no significance in EC and total dissolved solids (TDS). However, all major parameters indicate a statistically significant difference between the levels of Nitrates, Magnesium, Calcium, EC, TDS and TSS in Lake Water and irrigation effluents (Table 4) from one way Analysis of Variance (ANOVA), with all $\mathrm{F}$ values far above the critical 0.05 level. Table 6 shows a scoring and rating table for seventeen (17) indices, calculated from results in tables 1 and 2 , and considered most relevant for assessing irrigation suitability of waters. The results in table 6 indicate a $45 \%$ rating for point 2 and $40 \%$ rating for point 1 .

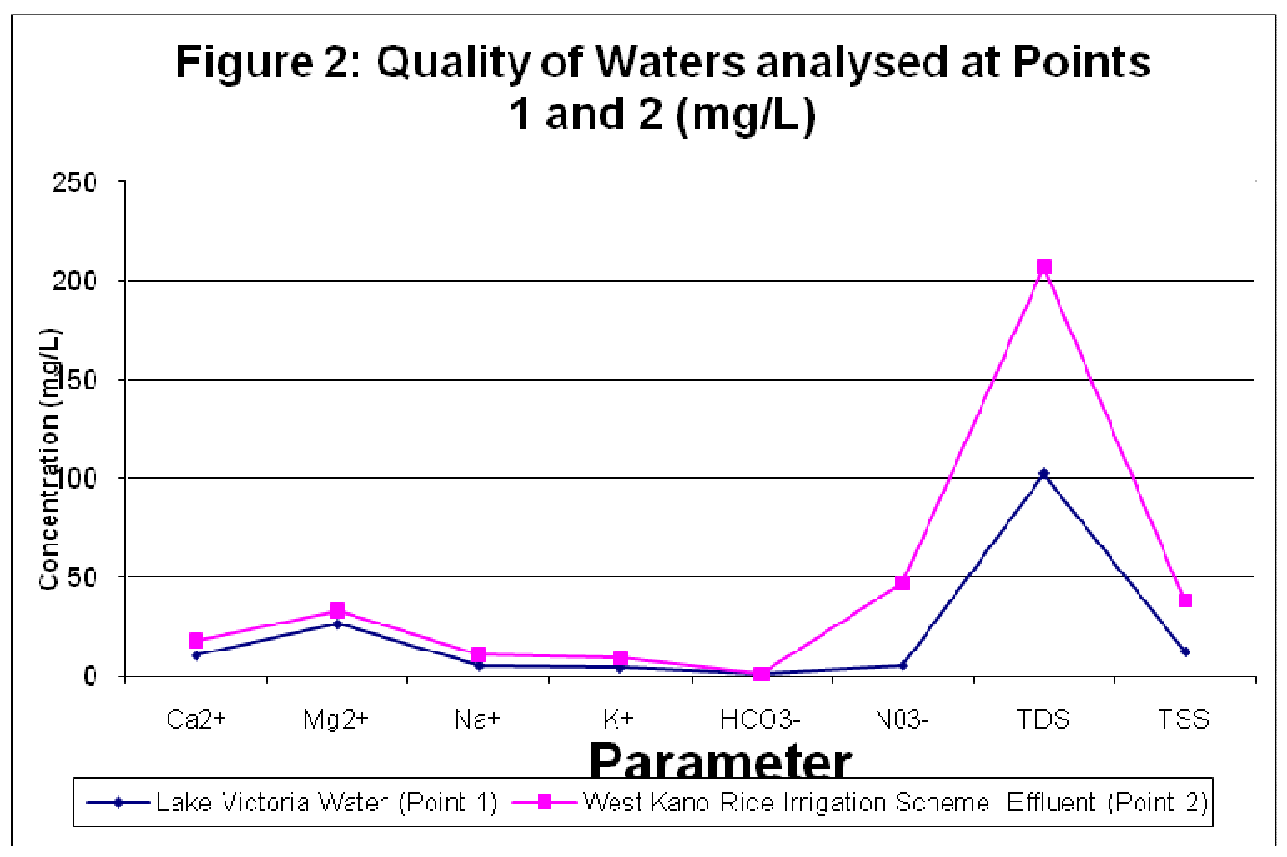

\section{Total Dissolved Solids, Electrolytic Conductivity and Salinity}

According to these results, taking

sample 2 to represent the wastewater, the TDS levels are significantly lower than these standards. The water can pose no salinity hazards to the soil if used for irrigation for years. The water is also not corrosive since its TDS exceeds 200mg/l (207 mg/L) ((Ayers and Westcott (1985) and Fipps (2004)). Low salinity water (TDS $<200 \mathrm{mg} / \mathrm{l}$ ) is corrosive and tends to deplete the surface soils of their soluble salts and exchangeable cations (Ayers and Westcott, 1985). This is applicable to water sample $1(107 \mathrm{mg} / \mathrm{L})$. Ca is most amenable to this washing. This reduces the strong stabilising influence it has on the soil aggregates and general structure. With less salts, especially Calcium, the soil disperses.

The finer soil particles fill in many of the smaller pore spaces, sealing the surface and greatly reducing water infiltration through the soil surface. This causes soil crusting and crop emergence problems (Hanks and Hill (1980)). Very low salinity waters result in water infiltration problems, regardless of SAR (Ayers and Westcott, 1985; and Hanks and Hill, 1980). These extra conditions put water from point 1 in very awkward situation since it has the soil corroding characteristics. Owing to this, the irrigation return flows, with higher TDS, could be much better and more compatible with the soils if used for irrigation (Fipps, 2004). The rate of soil calcium washing 
is directly proportional to the difference in calcium levels between the soil and the irrigation water. Similarly, the rate of irrigation wastewater calcium enrichment is directly proportional to the difference in calcium concentrations of the irrigation water and the soil. Whereas the scope of this research does not allow for further development of the soilnutrient loss and water nutrient enrichment models, it hopes it is researched on further.

According to ILACO (1977), and Kovda et al (1973), normal (non-saline and non-alkaline) water (TDS range 200-500 $\mathrm{mg} / \mathrm{L}$ ) has usually ameliorating effects if employed in the irrigation of alkaline soils. Calcium usually dominates among the cations of such waters. After several decades of irrigation by fresh Calcium bearing waters, alkaline soils have a lower $\mathrm{pH}$ and their physical, chemical and biological properties are greatly improved (Russel (1973), Hanks and Hill (1980), and Fipps (2004)). In WKRIS, there is a danger of soil loss of $\mathrm{Ca}^{2+}$ since the calcium concentration in irrigation water is much lower than the soil calcium concentration. West Kano clays are montmorillonitic; they contain Aluminium hydroxide films which could help stabilise dry season cracks to some extent (NIB, 1999). On the other hand, the soils can only be irrigated with waters of lower salinity than $250 \mu \mathrm{Scm}^{-1}$ because of the low drainage (Russell, 1973). Due to this, even when wastewater recycling is eventually adopted, there is need to continuously monitor the salinity levels lest they exceed the critical levels (Hanks and Hill (1980). As these levels are reached with time, blending with the lake water could be resorted to. This could ensure a continuous use of only good quality waters.

The nitrate is another nutrient than forms a significant part of TDS, because of its high solubility and close association with divalent cations, especially calcium. The nitrates in effluents could act as crop nutrients, since nitrogen is a macronutrient required for formation of amino acids, which aid in plant growth (Salisbury and Ross, 1992). On the other hand, low nitrate levels in sample 1 would require an addition of fertilizers, since souls would generally be leached by the low TDS waters. From flow rate measurements, as well as calculations using volumes of effluents compared with annual crop requirements, a total of 12.26 million $\mathrm{m}^{3}$ of water is pumped from
Lake Victoria into WKRIS annually, while 8.94 million $\mathrm{m}^{3}$ of water is pumped out annually from the WKRIS back to Lake Victoria (Afullo, 1995). This net volume of water pumped out of the scheme, coupled with the nitrate load, renders nitrate a very significant constituent of the TDS.

\section{Sodium Adsorption Ratio (SAR) and Adjusted SAR $\left(S A R_{a d j}\right)$ of The Irrigation Water}

SAR is the proportion of sodium present in the soil, and represents the sodium hazards of water. It is defined by the ratio of ${ }^{\mathrm{Na}+}$ concentration to the sum square root of the average concentrations of $\mathrm{Ca}^{2+}$ and $\mathrm{Mg}^{2+}$ (Fipps (2004), and Ayers and Westcott, 1985). The percentage of $\mathrm{Na}^{2+}$ is generally less than $5 \%$ of the total exchangeable cations. If this percentage increases to at least 10 , the aggregates of soil grains begin to break down. The soil becomes less permeable and of poor tilth. It starts crusting when dry, and it becomes alkaline. High sodium soils are, therefore, plastic and sticky when wet and prone to clod and crust formation when dring. Excess sodium in irrigation waters also promotes soil dispersion and structural breakdown if sodium exceeds calcium by more than 3:1 (Hanks and Hill (1980). This results in severe water infiltration problem due to soil dispersion, plugging and sealing of surface pores, as does the low salinity water (Ayers and Westcott, 1985). This is due to lack of sufficient $\mathrm{Ca}$ to counter the dispersion effects of Na. The maximum acceptable SAR is $15 \%$ (Ayers and Westcott (1985); and Fipps (2004)). The effluent has $35 \%$, while the current water source has $18 \%$ SAR, rendering both of poor irrigation quality, though the effluents have a compensatory advantage due to its higher levels of $\mathrm{ca}^{2+}(0.91 \mathrm{me} / \mathrm{l})$, compared with the Lake water's $0.48 \mathrm{me} / \mathrm{l}$. SAR, however, does not take into account the Calcium fixation by the carbonates and bicarbonates, making the adjusted SAR $\left(\mathrm{SAR}_{\mathrm{adj}}\right)$ a more realistic criteria (NIB, 1999). The adjusted SAR is more important since it takes into account the levels of even some of the anions, bicarbonates and carbonates in the irrigation waters. These anions immobilise $\mathrm{Ca}^{2+}$ by forming precipitates with it, thereby reducing its concentrations in solution. This leaves behind the $\mathrm{Mg}^{2+}$ to play the role of keeping the soil structure, a role it plays less 
efficiently. It is calculated from an adjusted $\mathrm{Ca}^{2+}$ concentration of the irrigation water (Fipps (2004). The $\mathrm{Ca}^{2+}$ levels are adjusted to the expected equilibrium values, and it can be used to predict more precisely the potential soil infiltration problems due to relatively high sodium (Ayers and Westcott, 1985 and NIB, 1999)). The effluents have $32 \% \mathrm{SAR}_{\mathrm{adj}}$, compared with $16 \%$ for the lake water. Kinyali, (1973) found that irrigation water with a low conductivity of $100 \mu \mathrm{Scm}^{-1}$ can have a SAR of up to $10-18 \%$ if the ESP of the soil is to remain less than 7.5 and $15 \%$. The management steps available for the soil and /or water chemistry changes are chemical. These are aimed at influencing the soil infiltration rates, and are extremely expensive. They can be accomplished by adding a chemical amendment (such as gypsum) to either the soil or water. In a few cases, blending two or more sources of water of different chemical composition can be used (Fipps (2004) and Hanks and Hill (1980).). This is where the calcium/sodium levels in the different waters analysed become handy. Commercial amendments in the form of gypsum (Calcium Sulphate) addition into irrigation waters are the most common method. This amendment is already available in the WKRIS wastewater and can be a cost-effective form to exploit.

\section{Calcium Related Ratios and Sustainable Irrigation}

Ayers and Westcott (1985) set the minimum recommended ratio of $\mathrm{Ca}$ : $\mathrm{Na}$ to be 3:1. The effluent has a ratio 3.35: 1 , while the Lake water has a ratio less than 3: 1 . Thus the wastewater qualifies for sustainable use in irrigation in WKRIS. However, $\mathrm{Ca}$ and $\mathrm{Mg}$ are antagonistically absorbed by plants and adsorbed to the soil colloidal surfaces (Ayers 1985). This makes the ratio Ca: Mg important. The higher the ratio, the better for the soil structures, especially if the ratio exceeds $50 \%$ (Hanks and Hill (1980); and Ayers and Westcot, 1985). The WKRIS effluent has $32.8 \%$, while Lake Victoria water has $22.1 \%$ the irrigation wastewater thus rates the better source for use in sustainable irrigation. Lower ratios than $5 \%$ are expected to causes complete soil and water imbalances. Another important $\mathrm{Ca}$ ratio is that of $\mathrm{Ca}$ to total cations. At least $10-15 \%$ is needed for optimal root growth of cereals and cotton (Ayers and Westcott, 1985). Again, the wastewater offers the best quality ratio of $20.8 \%$, while the current WKRIS irrigation water has a ratio less than the recommended range, recording only $16.2 \%$. Therefore in all Calcium related criteria, the effluent rates the better for sustainable irrigation in WKRIS.

\section{Soil and Water Amendments.}

Certain chemical amendments added to soil or water improves a low infiltration rate caused by low salinity or by excessive sodium (high SAR) in the irrigation waters. Improvements can be expected if the amendment increases the soluble Ca content or causes a significant increase in the salinity of the applied water Gypsum will do exactly this (Ayers and Westcot, 1985). Water amendments are most effective if the water infiltration rate is caused by low salinity water $\left(\mathrm{EC}<200 \mu \mathrm{Scm}^{-1}\right)$ or by a high SAR in a low to moderate salinity water $\left(\mathrm{EC}<100 \mu \mathrm{Scm}^{-1}\right)$. In this particular case of WKRIS, water amendment is most appropriate since the irrigation water is too corrosive (i.e. has low salinity). In any case, the Calcium Sulphate already in the irrigation wastewater can be a sufficient amendment if adopted. Another possibility is the blending of this return flow with the lake water to get the best quality water for use. In terms of $\mathrm{pH}$, the standards set by FAO (Ayers and Westcott, 1985, and Fipps, 2004) for the best $\mathrm{pH}$ range is for irrigation water is $6.5-8.4$, which is satisfied by both waters. The bicarbonate levels earlier discussed are important in both $\mathrm{pH}$ modification and sprinkler irrigation (Hanks and Hill (1980). However its effects with respect to the latter are irrelevant to this study because sprinkler irrigation is not used in WKRIS.

\section{Conclusion}

The WKRIS effluents are heavily enriched with Nitrates, Sulphides and TDS. The irrigated soils are losing these nutrients, which in turn are disposed of into, and polluting Lake Victoria. It is therefore useful to stop the disposal of the effluents into the lake and get alternative disposal mechanism. In its current state, the effluent is more suitable for irrigation than the current irrigation water source, with an irrigation suitability rating of $45 \%$ and $40 \%$ respectively. Its use is therefore recommended as it requires no blending in its current state. However, when the recycling 
eventually starts, the quality of the wastewater should be regularly monitored to ensure that blending is embarked on as soon as the quality deteriorates significantly for continued recycling. Further research should also be done on the lake basin industries to assess the reuse potential for their effluents, and a soil irrigability study to be able to match the soil quality dynamics associated with WKRIS irrigation history.

\section{References.}

Afullo, A (1995). Pollution of Lake Victoria by inorganic fertilisers used in the West Kano Rice Irrigation Scheme. An Unpublished MPhil Thesis, Moi University, School of environmental studies, Moi University, Eldoret, Kenya.

APHA, AWWA and WEF (2005) Standard methods for the examination of water and wastewater. American Public Health Association (APHA), American Water Works Association (AWWA) and Water Environment Federation (WEF). Pp 1368. Supplement to the $21^{\text {st }}$ Edition, Alexandria, USA.

Ayers, R. S. and Westcot, D. W. (1985). Water quality for agriculture. FAO irrigation and drainage paper No.29 Rev 1. FAO of the UN, Rome. ISBN 92-5-102263-1.

D'Costa, V. (1973). Characterisation and interpretation of the soils of the Kano plains for irrigation agriculture. Unpublished M.Sc. Thesis, University of Nairobi.

EMCA (1999). The Environment Management and coordinating Act of 1999. Ministry of Environment and Natural resources, Government of Kenya. Published by Government printers, Nairobi.

Fipps G (2004). Irrigation water quality standards and salinity management strategies. Texas cooperative extension, Texas, USA.

Kovda, V A, berg C, Van den and Hagan R M. (Eds) (1973). Irrigation, Salinity and drainage: An international source book. Hutchinson \& Co. Ltd. Hutchinson, FAO and UNESCO. Moscow, USSR.

GoK (1999). The environmental management and coordinating act (1999). Government of Kenya, Nairobi.

GoK (2003) National development plan. Ministry of planning and national development. Government Printers, Nairobi. GoK (2003b) Nyando District Development plan. Ministry of planning and national development. Government Printers, Nairobi
GoK, (2005) Achieving Millennium development goals in Kenya: A needs assessment and costing report. National development plan. Ministry of planning and national development. Government Printers and UNDP, Nairobi.

GoK (2006) West Kano Irrigation Scheme annual climatic data. Ministry of Environment and natural resources, Nairobi. Government printers, Nairobi, Kenya.

GoK (2007). Vision 2030. Government of Kenya. Ministry of planning and national development. Government printers, Nairobi.

Gregg, L. W (1989). Water analysis handbook. $5^{\text {th }}$ edition. Hach. Loveland, USA.

Hanks R J and Hill W (1980). Modelling crop responses to irrigation in relation to soils, climate and salinity. International Irrigation Information Centre (IIIC), Bet Dagan, Israel. ISBN: 0080255132.

Hunt, O. T. E. and Wilson, A. L. (1986). The chemical analysis of water: General principles and techniques. 2nd edition. Water research centre Mediterranean laboratory. SpringerLINK.

ILACO (1977). Ahero irrigation research station- Kenya- research results 1976 (Nov. 1975-Nov. 1976). National irrigation board/ Ministry of Agriculture/ Kingdom of the Netherlands.

Kim, H.K, Jang, T.I., Im, S.J. and Park, S.W (2009). Estimation of irrigation return flow from paddy fields considering the soil moisture. Agricultural Water Management, Vol. 96, Issue. 5, pp. 875-882.

Kinyali, S. M. (1973). Long term effects of variable water quality on some soil physical characteristics under field conditions. Unpublished M.Sc. Thesis, University of Nairobi, Kenya.

Lebel G G. and Kane H. (1987) Sustainable development: A guide to our common future. The report of the world commission on environment and development (WCED), Oxford University, press, England.

Mason C. F. (2002). Biology of fresh water pollution. $4^{\text {th }}$ edn. Pearson prentice Hall. Amazon New York Series, Great Britain. ISBN: 0130-90639-5.

Mohan, S. and Vijayalakshmi, D.P. (2009. Prediction of irrigation return flows through a hierarchical modeling approach. Agricultural Water Management, Vol. 96, Issue. 2, pp. 233246. 
Mukumbu M (1987) Determination of optimal enterprises mix and the resources allocation for WKRIS. An Unpublished MSc Thesis, University of Nairobi.

NIB (1999) National Irrigation Board. Technical Reports \#s 17, 23 and 28. National irrigation board, Ahero, Kisumu, Kenya.

Russel E. W. (1973). Soil conditions and plant growth. 10th edition. Longman, London.

Salisbury and Ross. 1992. Plant Physiology. Fourth edition. Belmont, CA: Wadsworth, USA.

Shinberg I and Oster J. D. (1978). Quality of irrigation water. Publication No. International Irrigation Information Centre (IIIC), Bet Dagan, Israel.

Smet J and Wijk C.V. (2002).Small community water supplies: Technology, people and partnership. IRC Technical paper series 18. International Reference centre for community water supply and sanitation, The Hague, Netherlands.

Urama K and Mwendera E (2005).SocioEconomic and Environmental Consequences of Agricultural Technology: A Comparative Study of Small Scale Surface Irrigation Technology in Nigeria and Swaziland. ATPS Working Paper Series No. 43 African Technology Policy Studies Network (ATPS) Nairobi, Kenya. ISBN: 9966-916-58-X.

Wandhahwa, P (1988). Comparison of single and double cropping of rice on the physical properties in relation to tillage of a vertisol. An Unpublished MSc Thesis University of Nairobi (UoN), Nairobi, Kenya..

WKRIS Quarterly reports (1988). The West Kano Rice Irrigation Scheme Quarterly reports. National Irrigation Board, Ahero, Kenya.

Table 1: Quality of the Lake Victoria waters at points 1

\begin{tabular}{|l|l|l|l|l|l|l|l|l|l|l|l|}
\hline parameter & $\mathrm{Ca} 2+$ & $\begin{array}{l}\mathrm{Mg} 2 \\
+\end{array}$ & $\mathrm{Na}+$ & $\mathrm{K}+$ & $\begin{array}{l}\mathrm{HCO} \\
3-\end{array}$ & N03- & TDS & TSS & pH & EC & Temp \\
\hline Units & $\begin{array}{l}\mathrm{Mg} / \\
\mathrm{L}\end{array}$ & $\begin{array}{l}\mathrm{Mg} / \\
\mathrm{L}\end{array}$ & $\begin{array}{l}\mathrm{Mg} / \\
\mathrm{L}\end{array}$ & $\begin{array}{l}\mathrm{Mg} / \\
\mathrm{L}\end{array}$ & $\begin{array}{l}\mathrm{Mg} / \mathrm{L} \\
\mathrm{Mg} /\end{array}$ & $\begin{array}{l}\mathrm{Mg} / \\
\mathrm{L}\end{array}$ & $\begin{array}{l}\mathrm{Mg} / \\
\mathrm{L}\end{array}$ & - & $\begin{array}{l}\mu \mathrm{Scm}- \\
1\end{array}$ & $0 \mathrm{C}$ \\
\hline Point 1 & 10 & 26 & 5 & 4 & 0.8 & 5 & 102 & 12 & 7.3 & 110 & 23.4 \\
\hline
\end{tabular}

Table 2: Quality of the WKRIS wastewaters at point 2

\begin{tabular}{|l|l|l|l|l|l|l|l|l|l|l|l|}
\hline $\begin{array}{l}\text { parame } \\
\text { ter }\end{array}$ & $\begin{array}{l}\mathrm{Ca} \\
2+\end{array}$ & $\begin{array}{l}\mathrm{Mg} \\
2+\end{array}$ & $\begin{array}{l}\mathrm{N} \\
\mathrm{a}^{+}\end{array}$ & $\begin{array}{l}\mathrm{K} \\
+\end{array}$ & $\begin{array}{l}\mathrm{HCO} \\
3^{-}\end{array}$ & $\begin{array}{l}\mathrm{N}_{3} \\
-\end{array}$ & $\begin{array}{l}\mathrm{TD} \\
\mathrm{S}\end{array}$ & $\begin{array}{l}\mathrm{TS} \\
\mathrm{S}\end{array}$ & $\begin{array}{l}\mathrm{p} \\
\mathrm{H}\end{array}$ & $\mathrm{EC}$ & Temperature \\
\hline Units & $\mathrm{Mg} / \mathrm{L}$ & $\mathrm{L}$ & - & $\mu \mathrm{Scm}^{-1}$ & ${ }^{0} \mathrm{C}$ \\
\hline Point 2 & 18 & 33 & 11 & 9 & 1.1 & 47 & 207 & 38 & $\begin{array}{l}7 . \\
0\end{array}$ & 187 & 23.3 \\
\hline
\end{tabular}

Table 3: Student's t-test values for the water samples 1 and 2.

\begin{tabular}{||l|l|l||l||}
\hline \hline & EC & TDS & $\mathrm{NO}_{3}{ }^{-}$ \\
\hline 1 & -13.18 & 321 & 18.18. \\
\hline 2 & 1.47 & 246 & $-27.1^{*}$ \\
\hline
\end{tabular}

* means statistically significant. 
Table 4: Results of one-way ANOVA between the water (point 1) and effluents (Point 2)

\begin{tabular}{|c|c|c|c|c|c|c|}
\hline Parameter & & Sum of Squares & df & Mean Square & $\mathrm{F}$ & Sig. \\
\hline \multirow[t]{3}{*}{$\mathrm{EC}$} & Between Groups & 10.144 & 5 & 2.029 & .842 & .534 \\
\hline & Within Groups & 57.856 & 24 & 2.411 & & \\
\hline & Total & 68.000 & 29 & & & \\
\hline \multirow[t]{3}{*}{ TSS } & Between Groups & .392 & 12 & .033 & .647 & .776 \\
\hline & Within Groups & .858 & 17 & .050 & & \\
\hline & Total & 1.250 & 29 & & & \\
\hline \multirow[t]{3}{*}{ TDS } & Between Groups & 15.500 & 9 & 1.722 & .850 & .581 \\
\hline & Within Groups & 40.500 & 20 & 2.025 & & \\
\hline & Total & 56.000 & 29 & & & \\
\hline \multirow[t]{3}{*}{ Nitrate } & Between Groups & .415 & 14 & .030 & 1.464 & .242 \\
\hline & Within Groups & .283 & 14 & .020 & & \\
\hline & Total & .699 & 28 & & & \\
\hline \multirow[t]{3}{*}{$\mathrm{Mg}$} & Between Groups & .427 & 11 & .039 & .818 & .625 \\
\hline & Within Groups & .855 & 18 & .047 & & \\
\hline & Total & 1.282 & 29 & & & \\
\hline \multirow[t]{3}{*}{$\mathrm{Ca}$} & Between Groups & 1.765 & 13 & .136 & 1.778 & .137 \\
\hline & Within Groups & 1.222 & 16 & .076 & & \\
\hline & Total & 2.987 & 29 & & & \\
\hline
\end{tabular}

Table 5: Descriptive Statistics for water and effluent quality (Mean and Standard error of the mean)

\begin{tabular}{|c|c|c|}
\hline Parameter and sampling point 1 or 2 & Mean concentration & Std. Error of mean \\
\hline $\mathrm{Ca} 1$ & 9.9900 & .0586 \\
\hline $\mathrm{Ca} 2$ & 17.9933 & .0661 \\
\hline $\operatorname{Mg} 1$ & 25.9833 & .0384 \\
\hline $\mathrm{Mg} 2$ & 32.9900 & .0729 \\
\hline $\mathrm{Na} 1$ & 4.9967 & .0290 \\
\hline $\mathrm{Na} 2$ & 11.0000 & .0875 \\
\hline K1 & 3.9900 & .0260 \\
\hline $\mathrm{K} 2$ & 9.0033 & .0454 \\
\hline $\mathrm{HCO}_{3}^{-} 1$ & .8020 & .0032 \\
\hline $\mathrm{HCO}_{3}^{-} 2$ & 1.1000 & .0240 \\
\hline $\mathrm{NO}_{3}{ }^{-1}$ & 4.9867 & .0291 \\
\hline $\mathrm{NO}_{3}^{-} 2$ & 46.9897 & .1468 \\
\hline TDS1 & 102.0000 & .2537 \\
\hline TDS2 & 207.0000 & .5425 \\
\hline TSS1 & 12.0033 & .0379 \\
\hline TSS2 & 38.0067 & .1602 \\
\hline PH1 & 7.2967 & .0212 \\
\hline $\mathrm{PH} 2$ & 6.9767 & .0383 \\
\hline $\mathrm{EC} 1$ & 110.0000 & .2796 \\
\hline EC2 & 187.000 & .314 \\
\hline TEMP1 & 23.4000 & .0254 \\
\hline TEMP2 & 23.3000 & .0288 \\
\hline
\end{tabular}


Table 6: Irrigation Critical Parameters, standards and Irrigation suitability ratings and scores of water samples from point 1 and point 2

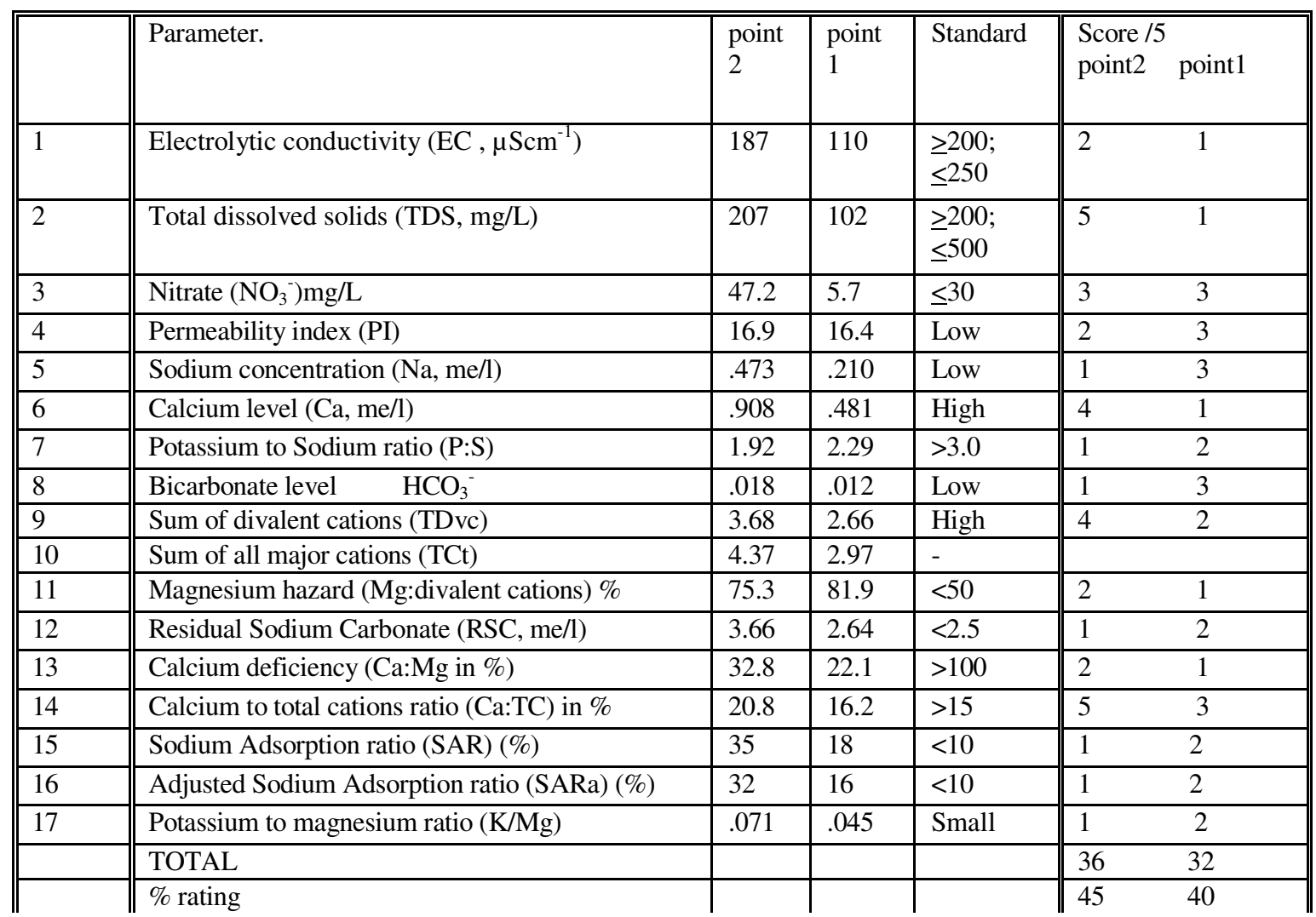

